\title{
Disassembling legal form: oznership and the racial body
}

Brenna Bhandar ${ }^{1}$

In 1984, John Moore commenced legal proceedings against his physician, Dr. Golde, Golde’s employers (the Regents of the University of California system), and pharmaceutical corporations involved in the exploitation of the Mo cell line, derived from cells removed from his spleen. ${ }^{2}$ Moore was being treated for hairy-cell leukemia, and Golde knew that the lymphokines ${ }^{3}$ produced by Moore's cancerous cells were potentially very profitable. Moore's spleen was removed during the course of treatment, and he did not consent to the commercial exploitation of his bio-waste. The plaintiff's action lay in the tort of conversion, alleging that Golde, Quan (Golde's assistant) and the other defendants had effectively converted cells from his spleen into a commercially profitable cell line without his authorisation. The California Supreme Court found that Moore did not have an action in conversion, as he did not have a proprietary interest in his cells. Moore $v$ Regents has been the focus of much scholarly attention, inviting as it does analysis of the rights of the individual to bodily integrity and dignity in the context of the biocapitalist exploitation of body parts (Rabinow 1996); the proprietary status of the cell line itself as a congealed network of hybridity (as both body part and intellectual product) (Strathern 1996, 535); the central role of bio-waste in the burgeoning bio-medical life science industries of the 1980s (Waldby and Mitchell 2006); and as a case in which reference to race and nation are utilised in order to illuminate newly emergent biotechnologies and their effects on the human (Wald 2005).

\footnotetext{
${ }^{1}$ My sincere gratitude to China Miéville, Sandro Mezzadra, and participants in the McGill Faculty of Law Legal Theory Workshop for their very insightful comments on an earlier draft. The omissions and errors which nonetheless persist remain my sole responsibility.

2 Moore v Regents (1990) 51 Cal.3d 120

3 Waldby and Mitchell note: "[1]ympokines are proteins used by the body's immune system and are of use and interest to many researchers. However, [they] are also notoriously difficult ot produce in large amounts, and so Golde saw great economic potential in Moore's cells." Waldby and Mitchell, 2006, 88
} 
In my view, this case provides a moment through which to think about the relationship between legal forms of property ownership, the body of the legal subject, and the racial. Taking as my point of departure the notion that property ownership, and the body of the legal subject to which ownership rights have historically attached are co-constituted through an analytic of the racial, the dispossession of Moore, a white male Alaskan engineer, of his body parts provides yet another moment (among so many) to think about how the disaggregation of the human body of the legal subject might provide an occasion for a radical interruption of the persistent fantasy of the self-possessed, unitary subject of rights. The dissenting judgment in Moore v Regents, that of Mosk J., explicitly invokes the spectre of slavery in arguing that Moore's self-possession of his body should be protected (see discussion below, at p.__ ). The literal, biological disassembling of the body of the self-possessed "I" threatens to place the proper legal subject of rights in extreme jeopardy, and this can only be safeguarded against by recognising a proprietary interest in one's self. Does the failure to preserve the integrity of John Moore's self-possession by the majority in Moore v Regents potentially unravel the legal forms of property ownership that simultaneously rely upon and constitute a notion of the legal subject whose body belies (and has always belied) its own phantasm of solely inhabiting whiteness, as unitary?

From what moment, at which point do we enter this old story? That is to say, the disaggregation of the human body with the advent of biotechnologies and the commodification of tissue culture, genetic databases, and other inscriptions of human life continue to raise a plethora of questions about the legal form of property, the networks of actors and objects that are productive of property, and the status (ontic, social, cultural) of the bodies (plant, animal, human) regulated by legal regimes of ownership. Questions of how technologies that embed proprietary invention within the biological organism itself collapse long-held distinctions between what is natural and what is made, what is social and cultural (Pottage 2007); or how the device of the patent congeals entire networks of labour and their attendant social relations (Strathern 2005), or shifts the temporal focus of ownership claims from past to future, may be of great utility in thinking about the shifting status 
of the human subject as it relates to the racial. Do emergent forms of property introduce new articulations of the body which in turn, might provide a basis for reconfiguring legal subjectivity? Or, does the abolition of the distinction between an ownership right that refers to an object and the object itself, which occurs with the emplacement of the right (over proprietary technology) within the body of the object perfect the "archaic figure of ius reale," rather than reinventing the legal form of property altogether? (Pottage 2009, 230-232) In other words, do emergent forms of property and their theorisations provide new frameworks through which to analyse long-standing and sedimented triangulations of legal form, the body and the racial?

Moore's proprietary claim occurs in the realm of biotechnologies that begin to re-write the human body as disaggregable, and this represents a collapsing of ontological categories that repeats itself over and over, in different guises, from the time modern property law emerges in the colonial context. For instance, Best explores how the Fugitive Slave Laws, by rendering the distinction between slave as object of ownership and subjective agent who incurs a debt through refusing to gift her labour to the white master totally ambiguous, lays the foundations for the disarticulation of the body and the recognition of intellectual property rights in such properties of the body as the voice (Best 2004, 81). Best writes:

The figuration of the fugitive as debtor produces a willful subject against the express legal nullifcation of willfulness. To be precise, it projects a willful subject when the will-less is in suspension, fabulates a subject not owned when the owned escapes (to use the language of common law) "absolute dominion," fantasizes a person at the precise moment when the security of property is subject to greatest question. (Best 2004, 81)

This is a moment where the distinction between slave as commodity and slave as a human person with volition is collapsed; the strict bounds of raciality are blurred as the "Negro" becomes legal person, if only for a moment, if only to be held accountable within a logic of market exchange and legal positivism. In addition to the racial logic of slavery revealing the germ of its contradiction, the legal form of ownership itself is challenged as object of ownership becomes subject who is caught within the contractual relations of appropriation of labour, debt and abstraction of personality, upon which property law is built. 
In shifting our focus on property law and its fantasies of its own stability and the legal subject, who in its abstraction, "does the dirty work of capitalist desires" (paraphrasing Best, 2004, 63), to a matter of legal form more generally, the question of the racial requires us to engage a postcolonial critique of capitalism (cf Chakrabarty 2000; Mezzadra 2011 a and 2011b; Ferreira da Silva 2007). The self-determining, autonomous 'I' was forged during the 18th and 19th centuries in relation to beings who fell outside of the bounds of cognisability in a burgeoning capitalist economic and political system: those whose labour was unfree, enslaved, and those whose lands were viewed as non-productive wasteland. For Marx, the legal subject is essentially living a phantasmic existence, rooted in the violence of abstraction and the commodity form. However, Marx's critique of the chimerical nature of this subject has had to be stretched (as Fanon noted, discussed below) to account for the ways in which the alienation of labour (the precondition for assuming the status of legal-political subject) assumes a subject who is self-possessed, and also, how the capacity for selfpossession and autonomy was thoroughly racialised and emplaced within a colonial logic (Spivak 1999; Ferreira da Silva 2007).

For instance, Fanon's devastating critique of the invention of settler and native explodes the distinction between form and substance, by repeatedly exposing how the fact of blackness (as both ontological category and lived experience) pervades the everday life of the colonial subject. Fanon reveals the fantasy of the autonomous, self-possessed individual whose body is intact as alwaysalready shattered and fragmented by a racial logic that relies on blurring the boundaries between beings (human subjects) and things (the animal, the slave as an instrument of production). What of the proper subject of the law, who finds quite literally its own body disaggregated by notions of the human inscribed as code? I seek to explore in the final part of the essay how (or whether) the racial is reconfigured with the disaggregation of the human body, the form essential to the political subjectivity of the self-determining, autonomous I. After exploring theories of the legal form that require the stretching alluded to (and executed) by Fanon, I want to shift the focus from the property 
relation as such to consider whether the re-writing of the human body reconfigures raciality; a valence and a logic that has shaped notions of human (and legal) subjectivity throughout modernity.

The first part of the chapter explores theories of the legal form as elucidated above; followed by a section on the relationship between the body and legal form. The final section of the chapter examines the judgment of Moore $v$ Regents of USC, a case in which the litigant asserts a right to ownership over a cell line produced from cells taken from his body during medical treatment, a claim which is rejected by the majority judgment. In the conclusion, I consider the ways in which the racial is re-deployed as the body of the legal subject is re-written not as the sum of its parts but as cells, tissue culture, as code. I argue that the racial is continually being re-written despite a moment of opportunity presented to us with the advent of various biotechnologies: to reveal (again) the fantasty of the self-determining ' $\mathrm{I}$ ' as a means of diminishing its power in the legal and political field. Increasingly interrupted by biotechnologies, in the same moment that new forms of propertisation, accumulation and appropriation take shape within the law, we seem to be in a moment that presents us with a space to re-shape legal-political subjectivities along different lines.

\section{Troo theories of the legal form and some deficits}

The question of the racial and its relationship to legal subjectivity is one that arises from our understandings of the legal form itself. For both Marx and Hegel, property lies at the basis of the legal form, yet what are the contours of the legal subject which they both assume in their theorisations of relations of ownership and contract? While Marx renders a critique of the phantasms that accompany the legal subject as property owner, Hegel posits ownership as central to the very becoming of the political-legal subject. The concept of form traverses the social, political phenomena that precede and exceed, that shadow the legal form itself. On a Marxist view, the legal form closely resembles the commodity form. The legal form mirrors and supports existing relations 
of production, property relations, and market forces. Because the legal relation's content is itself wholly determined by the economic relation (Pashukanis 1989, 96), there is no basis upon which one should, contra Kelsen (for instance), begin to theorise the legal form from an external vantage point of norms. Thus Pashukanis writes that "the legal relation is the cell-form of the legal fabric; only there does law accomplish its real movement. Compared to this, law as the aggregate of norms is merely a lifeless abstraction." (ibid, 85)

Abstraction functions as a more lively concept through its use, by Marx, as both a description and a critique of capital (Chakrabarty 2008, 58). Marx's labour theory of value is premised on the idea that the particularities of different kinds of labour are abstracted and congealed in the commodity as homogenous labour, as a part of the process by which use values are created (Marx 1990, 135-136). The abstraction of labour is the means by which use values are transmuted into exchange values. The violence of equivalence consists in the flattening of the differences between the labour necessary to produce different dimensions or aspects of a commodity, whereby concrete labour becomes the form of manifestation of its opposite, abstract human labour (ibid, 150). The abstraction of labour lies at the foundation of Marx's theory of commodity formation and thus, the theory of the legal form elucidated by both Marx and Pashukanis.

As Marx explains, the violence of abstraction also lies in its rendering invisible the social relations that are necessary for the production of goods. The very expression of value (the valuerelation of the products of labour within which the commodity appears) conceals a social relation.

It is nothing but the definite social relation between men themselves which assumes here, for them, the fantastic form of a relation between things. In order, therefore, to find an analogy we must take the flight into the misty realm of religion. There the products of the human brain appear as autonomous figures endowed with a life of their own, which enter into 
relations both with each other and with the human race. So it is in the world of commodities with the products of men's hands. (Marx 1990, 165)

This is the definition of commodity fetishism, a fetishism which is mirrored in the faith instilled in legal rights and entitlements that are attached to the legal subject. And it is at this juncture that an analysis of the specificities and particularities of the individuals who alienate their labour and those who cannot, and therefore fall out of the bounds of cognisability in this theory of the legal (and commodity) form becomes necessary. The congealing of the multiple dimensions of labour and production in the commodity not only obscures certain forms of labour and the social relations to which they are attached (Pashukanis 1989, 113), but the very subjects of these forms of production. By defining property law, which lies at the basis of the legal form, only in relation to the institution of private property defined as a relation between owners in the most formal sense, "jurists... exclude everybody but the owner from using and disposing of the object.... In these abstract prohibitions, the concept of property loses any living meaning and renounces its own pre-juridical history" (Pashukanis 1989, 122). While we may want to question what constitutes the pre-juridical (and whether this simply means pre-capitalist), the critique of the way in which property law is defined solely in relation to market relations and subjects who have the power to alienate the object of ownership continues to be relevant as contemporary scholarship turns ever more attention to the affective, inter-relational, and social dimensions of propertisation and ownership.

That property becomes the central focus of the theorisation of legal form is of no surprise. Marx emphasised that the property relation is the fundamental basis of the legal system. Because property becomes the basis of the legal form "only when it becomes something which can be freely disposed of in the market" (Pashuakanis 1989, 110), different ways of being, and different beings themselves are cast out from this regime of private property and legal recognition. He who is a slave, as a mere commodity, can only become a subject with legal personhood when he is able to act as someone who can dispose of commodities and participate in the market (Pashukanis 1989, 112, note 12). 
Defining legal personality on the basis of one's status as private property owner is nowhere more explicit than in Hegel's Philosophy of Right. For Hegel, private property ownership was central to the constitution of the legal political subject. It was only through the recognition of one's will, externalised into the object of ownership, that one became a full legal person. The Philosophy of Right is an attempt to theorise the simultaneous unfolding and development of the individual person's struggle for freedom in relation with others, and finally, through the reconciliation of the individual and universal Will as it is embodied in the ethical State. The realisation of the Idea, or concept, is governed by an inherent rationality; one that moves from the immediate rationality of the individual human being to the external world and relations with others and is finally realised in its universal form. Property ownership is central to this unfolding when considering rights in their abstraction and is also retained and held intact within civil society.

Of prime import to the self-determining subject is the struggle to reconcile his subjective will with that of the universal will. The will is the means through which freedom is actualised; it is the vehicle through which thought "translates itself into existence" (Hegel 1991, 35). The will is both the medium through which the self is reconciled to the universal - the will becomes one which has "being in and for itself" — and the locus of the desire and thought that propels the self through its dialectical progression towards mutual recognition with others and reconciliation with the universal (Hegel 1991, 52).

The capacity and desire of an individual to externalise his will in an object establishes private property ownership as the necessary pre-condition of recognition by and of others, and relatedly, founds the distinction between rational human beings and human beings who have yet to realise their individual personality in its completeness. In order to become embodied as a rational human being, the subject must "go out of himself" and "educate himself inwardly, in order so that he may become rational 'for himself"' (Hegel 1991, 45). The merely natural or immediate will is posited and embodied in an object and thus becomes capable of recognition by another being. In the movement of the "absolutely free will" in its abstract state towards its embodied being as a 
personality in the 'real' world, property takes on a central role (Hegel 1967, para 34). In order for the free will, the individual self-consciousness, to become a personality capable of holding legal rights, it must externalise itself in an object. Externalisation of the will in an object, and possession of that object (although that can take many different forms) is necessary for the free will to confront and relate to the external, 'real' world of things, and, also, to take on a form that will be recognised by other individuals. Thus the abstract will becomes embodied and gains recognition as such by another individual through his own possession of objects.

The contradiction inherent in externalising one's will into an object already occupied and owned by another results in what Hegel's refers to as a 'madness of personality' (Hegel 1991, para 62). ${ }^{4}$ The madness of personality results when there is no mediation between my exclusive, individual will and that of another in a single object (Hegel 1967, para 62). Ownership asserted by Europeans over land already occupied and used by Aboriginal communities; ownership asserted over self-possessed human beings as objects to be owned makes it tempting to conclude that a madness of personality is an apt description for the colonial settler context, were it not for the ascription of lower or less developed states of consciousness to Aboriginal communities, or for that matter, slaves. The will is crucial, as an enabling capacity, for the fulfillment of individuated human subjectivity. The slave has the capacity to reach this level of consciousness but not without engaging in a struggle for recognition. If the Phenomenology of Spirit and Philosophy of Right are understood as texts that unfold in a non-linear, non-chronological fashion, the slave to the contrary, seems to be very much caught within a progressive telos of development in which advancement can only be made through risking his life in battle. The slave is not only understood as having a lower or lesser developed form of consciousness, but moreover, Mbembe's critique of this Hegelian politics of

\footnotetext{
4 The issue of owning property that is already owned by another, for Hegel, is an impossibility because the object of ownership already contains or is replete with the will of the original owner. I can use, in a partial or temporary sense, a thing, but this form of possession is to be distinguished from ownership (Hegel 1967, para 62). The object contains a will that is impenetrable by my will. When I own something, that thing takes on an "independent externality" and is not just limited to my presence, to my knowledge and will in the present time and space (Hegel 1967, para 56). Recognition between two individual wills occurs through property; it is my individual will that is recognised through the medium of property by another individual will. Thus, there is a contradiction where two wills are present in the same object, and recognition is rendered an impossibility.
} 
death reveals how this telos sets the scene for sovereign control over the biopolitical reproduction and death of the racial subject in the post-colony (Mbembe 2003). While slaves have the capacity to fight for the realisation of truth through the coming into being of self-consciousness (as opposed to mere consciousness), it is beyond dispute that Hegel's play of world history places the colonial world as lagging behind Europe. The madness of personality is resolved by the force of property law that excluded colonised subjects from the bounds of the wilful, self-determining, autonomous ' $\mathrm{I}$ '.

The self-determining subject is, however, even in Hegel's own political-theology, a fractured, dislocated, disaggregated thing. It defies the absolute certainty, and thus the ontological closures that Hegel's dialectical logic is often accused of. Hegel as the author of a dialectic of recognition that entails violent closures in ontological and phenomenological registers, is also author of a text in which a resolutely dislocated body appears as Unhappy Consciousness. Even before the arrival of Unhappy Consciousness, Butler reminds us that the emergence of the body in the master/slave dialectic occurs, and it occurs as a moment of alienation. The self recognises itself but also recognises that it is not itself. Butler argues that the "self-recognition [of the bondsman] is derived from the radically tenuous status of the bondsman": he recognises himself in the forfeiture of the signature and the constant threat to his autonomy that the expropriation of the objects of his labour presents (Butler 1997, 39). This body constitutes my life, notes Butler, but this body there is equally me. I am in other words, both here and there; echoing the fractured subjectivity that migrants and refugees, to think of one example, inhabit as a matter of course (see Bhandar 2011). There is a spatial indecision that Butler speaks of that indicates a moment of being simultaneously embodied and alienated from oneself. In this moment, the self is not concerned with mastery but with trying to apprehend and give meaning to its split self; a split that is the very condition of its being. However, I refer to the ways in which Hegel forecloses these ruptures, particularly in relation to the body of the slave or non-Europeans, as discussed above.

Marx undoes this self-determining, autonomous ' $\mathrm{I}$ ' who is co-emergent with capitalist relations of production. Noting that mutual recognition as legal subjects can only occur as owners of private 
property, (Pashukanis 1989, 114; Marx 1990, 178); Marx, and Pashukanis after him, illuminate the false foundation of the 'will' and 'freedom' of the legal subject in a capitalist liberal democracy. Commodity exchange itself presupposes a conscious act of will on the part of the owner of the commodity in the context of the market, even though the commodity itself "acquires its value independently of the will of the producing subject (Pashukanis 1989, 112). As the owner is constituted within and by a juridical frame, "economic relations of ownership then give this subject a gift- (in compensation as it were) - a will, juridically constituted, which makes him absolutely free and equal to other owners of commodities like himself" (Pashukanis 1989, 114). Freedom and selfdetermination are inextricably linked, and indeed, expressed solely through market relations of exchange. This is what freedom means for the legal subject (or property owner).

The bounds of the self-determining, autonomous 'I' have been the site of contestation since its emergence in philosophical and political domains. Different forms of anti-colonial resistance have both attempted to stretch the bounds of the legal subject to include the colonised and to shatter them completely. The legal form, as dialectic, has been critiqued for failing to allow for the existence of a genuinely emergent plurality, rendering instead forms of legal pluralism that maintain the self-same identity of the sovereign, European, nation-state form or equivalent. It would be uncontroversial, I think, to argue that the legal form, as becomes manifest in a dialectic of recognition between nation states or between state and legal subjectivities that emerge in the modern colonial era, rely upon an analytic of the racial. In contemporary colonial settler contexts such as Palestine, for instance, the wasteland rationale used to appropriate the lands of others is still employed, reflecting the persistence of the notion of a proper subject of ownership who is quite thoroughly saturated with raciality. Colonial logics are de-territorialised and re-temporalised repeatedly, all over the globe.

In thinking about the body to which the subject is attached, Marxist theories of the legal form enact a different scene of erasure. Fanon points to the fissures in Marxist philosophy that are 
revealed in Marx's disregard of the bodies that signify the racial, and economic relations of the colony:

The originality of the colonial context is that economic reality, inequality and the immense difference of ways of life never come to mask the human realities. When you examine at close quarters the colonial context, it is evident that what parcels out the world is to begin with the fact of belonging to or not belonging to a given race, a given species. In the colonies the economic substructure is also a superstructure. The cause is the consequence; you are rich because you are white, you are white because you are rich. This is why Marxist analysis should always be slightly stretched every time we have to deal with the colonial problem. (Fanon 2001, 31, my emphasis)

The flight into the mystical realms of religion, a pre-condition for the realisation of a commodity fetishism which by definition obscures social relations between men is not afforded to the colonised. In the colony, economic relations never mask the violent social relations that characterise life there. Fanon's observation that one must begin with considering whether the colonial subject belongs to a given species makes precisely the interjection into the notion of human subjectivity that is needed in an anti or post-colonial reading of Marx. He raises the biological dimension of being and here and elsewhere brings into focus the very constitution of the body of the colonial subject (Bhandar 2011). Marx's concept of species-being is subjected, and needs to be subjected to this sort of thorough shaking from the outside. How does the very notion of the human species need to be re-thought in light of colonial violence? If the human person is only recognised as a legal subject through the externalisation of his will (which the colonised subject by definition lacks) in an object (which the colonised subject cannot own), to which species does the colonised belong? That the colonised subject is de-humanised, and indeed animalised is not a particularly contentious claim (Fanon 2001, 34). 
More specifically, the body of the colonial subject, the body of the slave, has always been fragmented in multiple ways. Skin as a site of desire, as a site of wounding, that has a politicaleconomic and symbolic significance all of its own (Fanon1967; Povinelli 2006); the dismemberment of the body that characterised colonial forms of domination in Africa (Mbembe 2003, 2011); the living death (Mbembe 2011) that characterises the colonial condition and the fact of blackness (Fanon 1967) that shapes the lived experience of colonial subjects in a non-totalising but dramatic fashion (Moten 2003), are all instances of the myriad ways in which the colonial (and slave) body has been disaggregated by a racial logic of subordination, with which as I have attempted to show, propertisation and the legal form were thoroughly imbricated.

Before, however, attempting to imagine a different species-being that is not bound by the strictures of the self-determining 'I' of capitalist-colonial economic relations, a different kind of accounting of the subject needs to take place. The disaggregation of the body of the proper, autonomous self-possessed legal subject as a result of advances in the life sciences industries has placed the form of this subject at risk. The hyper-commodification of the body touches the subjectivity of the self-possessed "I" that has hitherto had its fantasy of self-sovereignty protected by a legal form that assumed and relied upon it. In the following section, I offer an analysis of Moore v Regents of USC, taking note of how the California Supreme Court grappled with the challenge to Mr. Moore's bodily integrity and assertion of ownership over materials derived from his body. In the conclusion, I return to the question of the racial logic that persistently haunts the legal subject, and speculate on the productive challenges the disaggregation of the body of the legal subject might hold for legal-political subjectivities.

\section{Moore $v$ Regents: self-possession interrupted}


In the case of Moore v. Regents of University of California, the Supreme Court of California addressed the issue of whether John Moore, the plaintiff and appellant, had a legal cause of action for breach of the physician's disclosure obligations and for conversion. ${ }^{5}$ The facts of the case, briefly, were as follows: John Moore underwent treatment for hairy-cell leukemia at the Medical Centre of the University of California at Los Angeles (UCLA Medical Centre) in 1976. The doctors who treated him were aware that certain blood products extracted from Moore during the course of medical testing for his condition were "'of great value in a number of commercial and scientific efforts" and that access to a patient whose blood contained these substances would provided 'competitive, commercial, and scientific advantage." (P.1 of 40). Eventually in that same year, one of the defendants, Moore's treating physician Golde, recommended that Moore's spleen be removed in order to slow the progress of the disease. Moore signed a consent form authorising the splenectomy, however, neither Golde nor Quan, another physician defendant, informed Moore of their plans to use parts of his spleen for research. Nor did they request his permission. In fact, Golde negotiated agreements for commercial development of the cell line (derived from Moore's cells) and the products to be developed from it. Golde became a paid consultant with the Genetics Institute, and "acquired 75,000 shares of common stock" in the company. "Genetics Institute also agreed to pay Golde and the Regents 'at least $\$ 330,000$ over three years, including a pro-rata share of [Golde's] salary and fringe benefits, in exchange for... exclusive access to the materials and research performed' on the cell line and products derived from it." (P3 of 40) The deal that Golde reached with Genetics Institute was very lucrative indeed. The University obtained a patent on Moore's cell line, which covered various methods for using the cell line to produce lymphokines. Moore estimated that the market for such products would reach a value of approximately 3 billion USD by 1990 .

The Supreme Court found that Moore did not have a cause of action on the basis of conversion, but that he did have a cause of action for breach of a physician's fiduciary duty to

\footnotetext{
${ }^{5}$ Conversion is a tort that protects against interference with possessory and ownership interests in personal property.
} 
disclose. The Court considered whether the theory of conversion should be extended to apply to an individual's biological materials, and rejected this claim on three bases. The first was that "a fair balancing of the relevant policy considerations counsel against extending the tort. Second, problems in this area are better suited to legislative resolution. Third, the tort of conversion is not necessary to protect patients' rights" (p 12/40). The Court concluded specifically that the use of excised human cells in medical research did not amount to a conversion. The reasons for the rejection of the conversion claim are taken up most pointedly in Mosk J's dissenting judgment, which I discuss below. However, what is clear from the majority's rejection of this claim is that Moore's body parts were clearly being taken into the proprietary realm by Genetics Institute and the physicians, but were taken out of his proprietary control. The bodily aspects of subjecthood travel into the realm of policy objectives and social goods, and the commercial domain within which scientific innovation is lodged and sustained is hived off into a putative private realm. The body of the self-possessed legal subject in this instance becomes resolutely non-proprietary in relation to itself, while corporations engaged in the business of the life sciences potentially profit enormously from the bodily parts of the legal subject. One of the strongest justifications for rejecting the plea to extend the doctrine of conversion to apply to Moore's biological materials was the uncertainty that it would inject into the market of the life sciences and medical research:

Indeed, so significant is the potential obstacle to research stemming from uncertainty about legal title to biological materials that the Office of Technology Assessment reached this striking conclusion: " $[\mathrm{R}]$ egardless of the merit of claims by the different interested parties, resolving the current uncertainty may be more important to the future of biotechnology than resolving it in any particular way." (OTA Rep., supra, at p. 27 .)

The Court concluded that they "need not, however, make an arbitrary choice between liability and nonliability. Instead, an examination of the relevant policy considerations suggests an appropriate balance: Liability based upon existing disclosure obligations, rather than an unprecedented extension of the conversion theory, protects patients' rights of privacy and autonomy without unnecessarily hindering research." 
Recall that this is the 1980's when the life sciences industry is in its adolescence, and there was palpable fear about freezing the development of this market with potential litigation over the raw materials required to fuel this industry. They also drew upon Diamond v Chakrabarty (1980) 447 U.S. 303, finding that Moore's cells were factually and legally distinct from the patented cell lines and the products derived from it, and therefore, he had no property in the cell line.

Arabian J. in a concurring judgment, goes much further than Panelli J. in respect of the moral and ethical issues at stake in the claim. In very prosaic if not theological language, he finds that the plaintiff "entreats [the court] to regard the human vessel - the single most venerated and protected subject in any civilised society - as equal with the basest commercial commodity. He urges us to commingle the sacred with the profane. He asks much." (P18/40) Vehement in his conviction that human tissue should not be treated as a fungible article of commerce, he refuses to "deliver the majestic force of the law" to the ground beneath Moore's claim.

Mosk J., in a dissenting judgment, engages property as a bundle of rights, and finds that even where rights in relation to property are diminished, they remain an interest protected by property law. (At p25/40) He finds that the same logic applies to Moore's interest in his own body tissue: "even if we assume that section 7054.4 [of....] limited the use and disposition of his excised tissue in the manner claimed by the majority, Moore nevertheless retained valuable rights in that tissue. Above all, at the time of its excision he at least had the right to do with his own tissue whatever the defendants did with it: i.e., he could have contracted with researchers and pharmaceutical companies to develop and exploit the vast commercial potential of his tissue and its products" (p26). He re-affirmed the Court of Appeal's conclusion that to accept the position of the defendants, that they can own the plaintiff's tissue while he cannot, is rife with an irony that is legally untenable. Mosk J ultimately affirms the self-determining and autonomous 'I' as having property in his or her body, and the right to alienate that property for his or her own economic benefit. The ethical imperative to protect the body from inhumane and degrading treatment must be vigorously defended, and it is here that he explicitly invokes the spectre of slavery: "The most abhorrent form 
of such exploitation, of course, was the institution of slavery. Lesser forms, such as indentured servitude or even debtor's prison, have also disappeared. Yet their spectre haunts the laboratories and boardrooms of today's biotechnological research-industrial complex. It arises wherever scientists or industrialists claim, as defendants claim here, the right to appropriate and exploit a patient's tissue for their sole economic benefit - the right, in other words, to freely mine or harvest valuable physical properties of the patient's body."

The patenting of Moore's cell line was one instance of a growing "tissue economy" which heralded the quite radical shift in notions of human life. No longer dependent on being a part of a whole, human body, human life exists in in vitro for the first with the cultivation of the HeLa cells (Landecker, 2007). The HeLa cells are referred to in a footnote in this judgment, and not by name. The subtextual reference to the HeLa cells in the majority judgment, and the explicit reference to the institution of slavery in Mosk J's dissent, open onto a discussion of the place of the racial in the disaggregation of the body of this autonomous legal subject. If the body of the phantasmagorical autonomous 'I' has (also) always been fragmented, evinced most clearly by the body of the racial subject, does raciality as a logic implode, or is it reformulated, in these moments when the fantasy is explicitly challenged by the re-writing of the body as cell lines, or as genetic code?

\section{Conclusion: determining selves in an era of new bodily technologies}

When the body comes to be produced differently, and very much not as signifier of the mind but as signifier of cell or code, how does this reconfigure the racial that was tied to the ontoepistemological presupposition that privileged interiority and the self-same 'I'? (Ferreira da Silva, 2007) Biotechnological innovation makes it difficult to not take notice of how organisms, parts of bodies which are separated from the whole and continue a separate life of their own (immortal cell lines, for instance) fold exteriority into interiority, turning the outside into the inside and vice-versa. 
As we see in Moore $v$ Regents, the self-determination and freedom that are the preserve of the autonomous, legal subject are denied to him as the logic of new forms of capital accumulation and exploitation (now drawing on the material, physical resources of the body, rather than its expenditure in the form of labour) emerge with advent of biotechnologies in the life sciences. Indeed, Moore's very will to exert control over his bodily property, his freedom to contract in relation to his property, is denied; despite the fact that the sale of bodily parts (organs, blood, tissue) is not legally prohibited in the U.S. strictly speaking (see Moore v. Regents, per Mosk J.).

The onto-epistemological edifice that the modern human subject assumes, as Ferreira da Silva reminds us, that particular bodies that signify the mind, whereas other bodies signify nature" (2009). With the disaggregation of the human body by biotechnologies, the nature/culture divide (transposing Ferreira da Silva's critique into a related idiom), is shored up by intellectual property laws that rely upon a distinction between invention and discovery (Pottage and Sherman 2010). This idea of self-determination is re-configured by judgments dealing with body parts or life; the notion that one should be able to decide autonomously about what happens with one's very body and self, is interrupted by a proprietary regime that maintains a conceptual divide between the natural and cultural. The difference here, is that the subject who has always been assumed to be the natural progenitor of rights, self-determination and autonomy is undone by the imperatives of new forms of appropriation.

The legal form, however, still relies on the distinctions between the natural and the social, between nature/culture that built the edifice upon which the self-determining, autonomous 'I' sits, and ends up with sort of persistent jetlag that won't let newer inscriptions of the body live or die. Rather, they seem forced into a zombie state with raciality- as both a discourse and philosophicalscientific apparatus continuing to operate despite radical shifts in the relationship between human subjectivity and the body.

For instance, in the case of the HeLa cells, Hannah Landecker notes how the cell line of Henrietta Lacks, a young black woman who died of cervical cancer in the 1950s, comes to be 
described in popular and scientific journals in very racialised-sexist metaphors reserved for black women. As a part of the growing immortalisation of the human person through the culturation of cell lines in vitro, Lacks' cell line played a primary role as the first permanent strain of a human cell that could be used for experimental use (Landecker 2007, 127). Landecker notes how raciality and scientific innovation become fused with the discovery that HeLa cells had "contaminated and overgrown many of the other immortal human cell culture established in the 1950s and 1960s" (Landecker 2007, 168). In 1967, Geneticist Stanley Gartler announced to an audience, that having analysed eighteen different cell lines, all had the same profile as the HeLa cell. Because the key piece of evidence was the "profile for a particular enzyme called G6PD... a factor in red blood cell production", Garter concluded that The type of G6PD variant present in all cell lines was a type "found only in Negroes" (ibid, 168-169). Landecker observes that from this point onwards, the contaminating cell lineis marked as black, and the contaminated as white (ibid, 169). From this moment onwards, race becomes a key aspect of the HeLa narrative, with metaphors of miscegenation used to describe cells in culture and the threat posed by contamination- one drop of HeLa was enough to take over any other culture (ibid, 170).

Drawing on an example from the realm of genetics, Donna Haraway describes how in the early 1990's, the organisers of the Human Genome Diversity Project wanted to adjust the thinking of the mainline Human Genome Project by collecting hair-root, white blood-cell, and cheek-tissue samples, to be held in the American Type Culture Collection, from over 700 groups of indigenous peoples on six continents. She notes that modernist perspectives "distorted the definition of the categories of people from whom samples were to be sought, leading to a vision of dynamic human groups as timeless 'isolates of historic interest'. She notes that other potentially genetically distinct ethnic communities did not appear on the sampling list (Haraway 1997, 249). The subject/object divide, again, challenged by the very technologies used to map the human genome, such as recombinant DNA techniques, remain intact in the way that raciality is understood and signified. Blood remains the medium through which raciality is marked, echoing 19th century concepts of 
raciality that buttressed miscegenation laws and eugenics. The body- and changes in how human life is conceived of- could interrupt the legal form that wants to cling to late modern proprietary regimes of recognition (perhaps as it always could have), by harnessing the plasticity and instability manifest in the body and its parts. It is from a position of instability that political practices that disrupt the spatial fixity and the temporal closure of a singular, linear telos, which have characterised colonially embedded relations of being and property ownership could emerge.

\section{Works Gited}

Best, Stephen 2004 Fugitive's Properties: The Poetics of Law and Possession Chicago: University of Chicago Press

Bhandar, Brenna 2011. "Plasticity and Post-colonial Recognition: Owning, Knowing and Being" in Law and Critique Vol. 22 No. 3 pp227-249

Butler, Judith. 1997. The Psychic Life of Power: Theories in subjection. Stanford: Stanford University Press.

Chakrabarty, Dipesh 2000. Provincialising Europe: Postcolonial Thought and Historical Difference Princeton: Princeton University Press.

Fanon, Frantz 1967. Black Skin, White Masks (trans: Markmann, C.L.). New York: Grove Press.

Fanon, Frantz 2001. The Wretched of the Earth London: Penguin Books.

Ferreira da Silva, Denise 2007. Towards a Global Idea of Race Minneapolis: University of Minnesota Press.

Ferreira da Silva, Denise 2009. "No-bodies: Law, Raciality and Violence" in Griffith Law Review 18 (2), August.

Haraway, Donna J. 1997.Modest_Witness@SSecond_Millenium.FemaleMan_Meets_OncoMouse : Feminism and Technoscience London: Routledge

Hegel, G.W.F. 1967. Philosophy of Right (trans.) T.M. Knox Oxford: Clarendon Press

Hegel, G.W.F. 1991. Elements of The Philosophy of Right Allen W. Wood (ed.) Cambridge: Cambridge University Press.

Landecker, Hannah 2007. Culturing Life: How Cells Became Technologies London: Harvard University Press

Marx, Karl 1990. Capital Volume I. London: Penguin 
Mbembe, Achilles 2003. On the Postcolony Berkeley: University of California Press

Mbembe, Achilles 2011 "Provincialising France?" in Public Culture Vol.21 No.1

Mezzadra, Sandro 2011 a. "Bringing Capital Back In: a materialist turn in post-colonial studies?" in Inter-Asia Cultural Studies, 12:1, 154-164

Mezzadra, Sandro 201 1b. "How Many Histories of Labour? Towards a Theory of Post-Colonial Capitalism" in Postcolonial Studies, Vol. 14, No. 2, pp. 1-20

Moten, Fred In the Break: the aesthetics of the black radical tradition Minneapolis: University of Minnesota Press

Pashukanis, Evgeny 1989. Law and Marxism: A General Theory. London: Pluto Press

Pottage, Alain 2007. "The Socio-Legal Implications of the New Biotechnologies" Annu. Rev. Law Soc. Sci. 3:3.1-3.24

Pottage, Alain 2009. "Fiction science and proprietary effect" in Gaudillière Jean-Paul, Daniel J. Kelves, Hans-Jorge Rheinberger (eds) Living Properties: Making Knowledge and Controlling Ownership in the History of Biology Max Planck Institute for the History of Science

Povinelli, Elizabeth 2006. The Empire of Love: Toward a Theory of Intimacy, Geneology, and Carnality. Durham: Duke University Press.

Rabinow, Paul 1996. Essays on the Anthropology of Reason Princeton: Princeton University Press

Spivak, Gayatri 1999. A Critique of Post-Colonial Reason: Towards a History of the Vanishing Present Cambridge: Harvard University Press

Strathern, Marilyn 1996. "Cutting the Network" in The Journal of the Royal Anthropological Institute Vol. 2 No. 3, 517-535

Strathern, Marilyn 2005. Kinship, law and the unexpected: relatives are always a surprise Cambridge: Cambridge University Press

Wald, Priscilla 2005. "What's in a Cell? John Moore's Spleen and the Language of Bioslavery" in New Literary History, Vol. 36, No. 2, Spring, 205-225

Waldy, Catherine and Robert Mitchell 2006. Tissue Economies: Blood, Organs, and Cell Lines in Late Capitalism London: Duke University Press 